\title{
SHIFTING PARADIGM OF GovernanCe IN THE NATURAL RESOURCES MANAGEMENT OF BANGladesh: A CENTRAList TO PluRalistiC APPROACH IN THE FOREST Protected Areas Management
}

\author{
A. Z. M. Manzoor Rashid ${ }^{1, *}$, Donna Craig ${ }^{2}$ \\ and Sharif Ahmed Mukul 3,4 \\ ${ }^{1}$ Department of Forestry and Environmental Science, School of Agriculture and Mineral \\ Sciences, Shahjalal University of Science and Technology, Sylhet 3114, Bangladesh \\ ${ }^{2}$ Environmental Law, School of Law, Western Sydney University, \\ Sydney NSW 2751, Australia; craig.grace@wsu.edu.au, \\ ${ }^{3}$ Tropical Forests and People Research Centre, \\ University of the Sunshine Coast, Maroochydore DC QLD 4556, Australia; \\ sharif_a_mukul@yahoo.com \\ ${ }^{4}$ Tropical Forestry Group, School of Agriculture and Food Sciences, \\ The University of Queensland, Brisbane QLD 4072, Autsralia \\ * Corresponding author: rashid-fest@sust.edu
}

\begin{abstract}
Good governance in natural resource management (NRM) is one of the most challenging issues in developing countries that often inappropriately embedded in national policies and political agendas. It is, in fact, even more important for countries like Bangladesh with exceptionally high pressure and dependence on its natural resources for sustaining rural livelihoods. Globally, nowadays, good governance is considered as one of the key factor for achieving the goal of sustainable development and biodiversity conservation. Bangladesh, of late has responded to that global zeal by involving local communities in the management of country's declining forest and other natural resources. The colonial legacy of the forestry sector of Bangladesh was planned and, managed as interim projects through donors' prescriptions. Thus, institutions, management processes and conservation outcomes were problematic. The conventional approach adopted by colonial and post-colonial regimes for forest management also proved to be inefficient due to its top-down management system. The absolute dependency on donor support, and their prescription sometimes worsened the situation both ecologically and socially. Global, regional and local trends supported the need for a different dimension in the governance paradigms. The introduction of a pluralistic approach, known as comanagement in protected areas (PAs) is an example of an attempt whereby shared governance mechanism are implemented to attain the desired goals of conservation that
\end{abstract}


will also address the livelihoods and aspirations of communities living in and around PAs of the country. However, in designing future forest and PA regimes the concern of the external aid support and attached conditions remain a reality that needs to be addressed. Adequate attention should be given to our vanishing biodiversity, culture and community livelihoods through devising an appropriate governance mechanism recognizing and supporting local rights, access and participation in the environmental management. It is now time to mainstream the adhoc nature of governance according to our national conservation strategy and policy frameworks in order to achieve the goals and objectives of the Bangladesh NRM sector addressing the human and community right of people in the specific context of forest protected areas management.

Keywords: co-management; livelihoods; conflicts; biodiversity conservation; sustainable development

\section{INTRODUCTION}

Sustainability and sustainable development (SD) are the most widely spoken terms in various development and management paradigms. They emerged to bridge the disconnection between development and conservation and to embrace various attributes like governance, participation, rights and access (Rogers et al. 2008). The international community now focuses on diverse concepts, strategies and processes to address SD. One of the growing concerns is biodiversity conservation that involves sustainable livelihoods, good governance and active community participation (Rashid et al. 2007).

Management of protected areas (PAs) is an evolving trend that also embraces active community participation as an essential element of governance hence pluralistic approach like co-management is getting amid attention globally (Rashid et al. 2013a, 2013b). Bangladesh is also responding to that evolving trend in its natural resource management (NRM) sector especially in forest PAs). However, the features of governance are still a limiting factor that demands careful consideration of the ecological, social and institutional attributes influencing various stakeholders particularly the community living in and around the PAs.

The rapid destruction of the biological resources in developing countries due to socioeconomic and political drivers ${ }^{1}$ brings the importance of PA conservation and management into limelight. With the growing global concern of sustainable use of forest resources to check rapid biodiversity loss and threatened ecosystem, each country has adopted some forms of legal framework to deal the issues of PA declaration and governance. As PAs are central for conservation oriented initiatives addressing $\mathrm{SD}$, it requires better understanding of the global concepts and local context (Orlovic-Lovren 2011). According to World Commission on Protected Areas (WCPA) protected area is:

An area of land and/or sea especially dedicated to the protection and maintenance of biological diversity, and of associated cultural and natural resources, and managed through legal and other effective means.

\footnotetext{
${ }^{1}$ Poverty, over population, resource scarcity and over exploitation of natural resources is the common drivers.
} 
Recently IUCN redefined the definition (based on the definition given in 1994) of PA through its World Conservation Congress (Dudley 2008) as:

A clearly defined geographical space, recognised, dedicated and managed, through legal or other effective means, to achieve the long-term conservation of nature with associated ecosystem services and cultural values.

Establishment of PAs has emerged as a key conservation strategy in the backdrop of rapid deforestation and biodiversity losses worldwide (DeFries et al. 2007; Ormsby and Kaplin 2005). Over the last few decades, the number and coverage of PAs has increased significantly in most parts of the world (Kaimowitz and Sheil 2007; McNeely and Scherr 2003), and currently there are more than 100,000 PAs globally, covering around $12 \%$ of the land surface (Scherr et al. 2004; Chape et al. 2003). Such development has also taken place in many developing countries in the tropics where biodiversity is rich and local communities are heavily relying on forest for sustaining their livelihoods (Koziell and Saunders 2001; Ghimire 1994). However, in many instances establishment of PAs has failed to achieve the desired conservation goals due to pure ecological focus and poor recognition of local and indigenous people's traditional forest rights and practices (Ormsby and Kaplin 2005; Craig 2002; Nepal and Weber 1995). Such exclusion has also led to conflicts and mistrust between PA managers and local forest user communities hence management and conservation goals of PAs were significantly obstructed (Borrini-Feyerbend 2002).

Local people's support and involvement for PA management has been viewed as an important element of enhanced conservation in recent years, especially in developing countries (Wells and McShane 2004; Nagothu 2003). This new approach of PA governance commonly known as co-management or collaborative management is a major emerging issue for conservation policy in many developing regions that has also been widely recognised and promoted by various international conservation agencies as a means of governance (Fisher 2003; Jeanrenaud 2002; Kothari et al. 2000). This strategy enables active participation of local community in PA management and most often offers them some direct and indirect benefits that help in sustaining their livelihoods apart from achieving conservation goals (Nagothu 2003).

\section{Aim ANd Scope of This Chapter}

Bangladesh, as one of the most densely populated countries in the world, had significant forest cover until the British colonial period, with about $20 \%$ forest cover, and even until 1980 was a home to about half the bird species and a quarter of all mammal species of South Asia (Poffenberger 2000). Various state interventions in support of conservation can be traced back to British Colonial period but very few of the conservation goals were met and the depletion of the forest and biological resources continued at an alarming pace resulting in the further shrinkage of the actual forest cover (FAO 2009). Various interim efforts were taken in the name of community forestry; social forestry that have brought about visible success in increasing physical coverage but failed to create a synergy between conservation and development goals due to the absence of active community participation in overall decisionmaking process (Alam 2009). Such disparities affected the overall governance mechanisms of 
the PAs in the country (see Rashid et al. 2013a, 2013b; Mukul et al. 2012; Mukul and Quazi 2009).

Under this backdrop, the Government of Bangladesh has started establishing PAs and initiated co-management to address the biodiversity conservation and livelihood of the forest dependent community (Chowdhury et al. 2009). Till today, the government has declared 38 PAs (according to IUCN PA Management Categories they belong to category II, IV and VI). Of them 20 PA's have so far been taken under the umbrella of shared governance widely dubbed as co-management (BBFD 2016), that covers less than $2 \%$ of the total land area of Bangladesh (Mukul et al. 2008). These figures are amongst the lowest in the world (WRI 2007), despite the country's exceptionally rich biodiversity favoured by its' unique geoclimatic conditions (Appanah and Ratnam 1992). Furthermore, a large portion of the rural poor are either forest dwellers or forest dependent for their subsistence (Roy and DeCosse 2006). Introduction of co-management is the mere attempt to address both ecological and socio-economic attributes.

The concept of co-management and its application in the PAs of Bangladesh is quite new. To promote the issues of conservation and sustainable local development through a shared governance system Bangladesh Forest Department (BBFD) has developed a program of forest co-management in five PAs in 2002 on pilot basis through an initiative called Nishorgo Support Project (NSP), with active support from USAID. This pilot project is further scaled up in the name of 'Integrated Protected Area Co-management' (IPAC) with broader magnitude covering wetlands along with the forest PAs (Rashid et al. 2013a). During the NSP period, five PAs (Lawachara National Park, Satchari National Park, Rema-Kalenga Wildlife Sanctuary, Chunati Wildlife Sanctuary and Teknaf Game Reserve) were considered as pilot sites to apply the concept of co-management. These sites are unique from the perspectives of biodiversity richness as well as for the high level of exploitation. The aim of this chapter is to share the experiences of different 'co-management' initiatives from two of these pilot sites and their effectiveness and acceptance to local communities, and finally put some recommendation based on the flaws of these initial initiatives.

This chapter is based on the outcomes of the empirical studies carried out in Chunati Wildlife Sanctuary and Lawachara National Park. Existing legal and policy frameworks developed by the international community that recognised and accepted governance as an integral element of achieving SD in NRM sector especially in PA management have also been considered while analysing the facts related to PA governance. The introductory section highlighted the concepts and salient features of governance and their relevancy to biodiversity conservation while the second section described the history and evolving trend of community oriented forest management in order to depict the existing scenario of governance in PAs. The role of local institution and active engagement of local community have also been examined through the case studies. The final part of the chapter concluded with suggestions for future improvement of the PA governance in the country.

\section{Protected Areas: Classical vs Populist Approach}

In the past PAs were established keeping the local communities and forest dependent people on the periphery by imposing restriction on access and rights over resources. The majority of the parks established before 1980's followed exclusionary state-run approaches, 
restricting customary usufruct rights of the local community (Mehta and Heinen 2001). One of the vivid examples of such type is the Kruger National Park in South Africa. Here, the local community was forced to leave the area where they had been living for generations (Fabricius et al. 2001). This conventional approach of PA management was largely been ineffective as it further worsened the situation through rapid destruction of biodiversity and natural resource base. Such exclusionary approach is also against the notion of sustainable development and human rights.

With the repeated occurrence of park-people conflict due to the restriction and replacement, there has been a growing concern and understanding among the international community that, such exclusion will further deteriorate the ecosystem and livelihood base of the local community. Wide scale adoption of shared governance with decentralized decisionmaking process is an attempt to address these tensions (Ferrari 2006). Various legal and policy interventions were devised that recognised local community and other major stakeholders as an integral part of the PA management. Active engagement and in many cases a decision making role with the advent of Populist Approach ${ }^{2}$, the concept of PA management has expanded from biodiversity conservation to human welfare and livelihood perspectives (Naughton-Treves et al. 2005). This approach to management has increasingly been contested in both developed and developing country context as the centralist approach of PA management proved inappropriate due to its management process and governance mechanism (McNeely et al. 2006).

\section{GOVERNANCE FOR SUSTAINABLE DEVELOPMENT AND BIODIVERSITY CONSERVATION: CONCEPTUAL ATTRIBUTES}

The concept of sustainability integrates social and economic dimensions as essential aspects of ecosystem conservation emphasizing poverty alleviation, community participation, social justice and equity (Craig 2006). Economic, environmental and social aspects of SD require sustainable livelihood support, improved environmental protection through the integration of modern science and widespread public participation and local governance. Apart from these, strong local institutions, capacity building and long term financial support from development partners in developing nations are also a prerequisite in achieving sustainability (Dubois and Lowore 2000). International legal and policy frameworks are also playing a crucial role in guiding and determining the role of governance in the NRM sector in general and PAs in specific. From Brundtland report to Agenda 21 (i.e., Forest Principles) and Convention on Biological Diversity (CBD) all reiterated the importance of SD as a preamble of all conservation and development initiatives.

Generally, governance deals with the formation of rules and decision- making procedures and helps operating social institutions based on these regulations. The term governance differs from the aspect of management. Governance addresses the attributes of decisionmaking processes and identifies the stakeholders behind making these decisions while management addresses the outcome of any decision (Bosselmann et al. 2008). Governance denotes the structure and process used by different social actors to formulate and influence

\footnotetext{
2 It is a political idea and activities that are intended to represent ordinary people's needs and wishes instead of excluding them from any forms of participation or decision-making process (oxford dictionary).
} 
the decisions on matters of community concern (Abrams et al. 2003). Fundamentally, governance is about power, relationships and accountability.

The context of governance varies significantly ranging from global, national and local setting to social and institutional setting (Carter et al. 2009). As more and more instances of decentralization and devolution of power are taking place in line with the international policy and legal principles, which are framed to achieve SD, the importance of governance has got momentum in the field of NRM. The concept of governance provides directives that need to look beyond the government towards a public-private-civil society partnership in order to overcome the limitations of the long practiced traditional top-down approaches (Berkes 2003). The introduction of co-management in the PAs management is such an attempt whereby community stakeholders are granted with user rights and operational responsibilities. With this development in practice, the term governance also takes various forms like good governance, environmental governance and protected area governance those needs be discussed for better understanding of these evolving trends.

\section{Environmental Governance}

Community participation, accountability, transparency and pro-poor policy changes are considered as crucial dimension of natural resource governance (Dahal 2003). With the growing concern of governance as a new mechanism, community people have started gaining their legitimate voice in the SD process. Furthermore, international policy instruments have developed best practice principles to enhance good governance in various sectors. With the adoption of action plan of the Rio Declaration through the Agenda 21 and the CBD principles, the scope of governance has clearly extended into the environmental conservation and sustainable use of biological resources. However, it is worthwhile to mention that conservation alone cannot solve poverty but can significantly help to prevent and reduce it through maintaining ecosystem services and supporting livelihoods (Naughton-Treves et al. 2005).

Co-management in PAs governance needs global policy and legal directions in order to mainstream it into national laws in most developing nations. Articles 8 and 10 of the CBD have immense significance, highlighting the importance of in-situ conservation, the recognition of indigenous people's rights and their traditional knowledge, and the importance of public-private partnerships.

\section{Protected Area Governance}

Governance is not only a key concept in the field of biodiversity conservation but also emerging as a significant concept in PA management (Balloffet and Marin 2007). In a PA context, governance has got various dimensions ranging from policy to practice, attitude to meaning and from investment to impact that can influence the management objectives of the PAs (Lockwood 2010). PA governance concerns the structures, processes and traditions that determine how this power and responsibilities are exercised. It is exercised over a broad spectrum of management and must be backed by proper legal and policy framework to address multi-faceted goals and priorities (Jeffery 2004). The conventional top-down 
approach of governance has already been augmented and replaced by the people centred management regime under different forms (Borrini-Feyerabend 2003). Borrini-Feyerabend et al. (2006) clarify PA governance by isolating it from management as:

Management is about what is done about a particular site or situation, governance addresses decisions, who makes these decisions and how.

A good number of international and regional initiatives have helped to shape a new direction for conservation governance applicable for PAs. The importance of governance as key factor in PA effectiveness came to light during the $5^{\text {th }}$ World Parks Congress (held in Durban 2003) of IUCN (Dearden et al. 2005) The CBD Programme of Work (PoW) on PA adopted in 2004 at the $7^{\text {th }}$ Conference of the Parties (COP) also generated new commitments and policy guidance for the global PAs (SCBD 2008) The Durban Congress also developed a set of 'good governance' principles based on the general attributes of the good governance principles and includes legitimacy and voice; subsidiarity; fairness and performance and accountability as basic components (Borrini-Feyerabend et al. 2004). As the principle of governance and its performance vastly depends on the nature of community participation, the following sections attempt to explore the basic attributes of community participation particularly in context of PA management in Bangladesh.

\section{DeVElopment OF PARTiCiPATORY Forest MANAGEMENT REgIME IN BANGLADESH}

There is a growing recognition and consensus among the policy makers that, traditional forestry practices need to be replaced by a more sustainable option of management (Muhammed et al. 2008; Ali et al. 2006). Participatory forestry in Bangladesh draws amid attention in this regard as a strategy both for resource management and community development (Khan 1998). Encompassing greater control over forest resources has created ample opportunities for participatory forestry and the possibilities to improve the livelihood of the local forest dependent people (Cronkleton et al. 2010). However, community participation is a difficult task in any society and situation which is more critical in developing country context like Bangladesh due to the socio-economic inequalities and absence of good governance (Khan et al. 2004). The trend of the participatory forest and PA management and their role in enhancing governance as an imperative to SD have been discussed in the following section.

\section{Community Participation in Forestry Sector: Existing and Evolving Trends}

Community participation in the forestry sector of Bangladesh is a recent development drawing momentum in the face of global recognition (Khan 2009). The FMP described and highlighted the participation as a new mission and challenge to develop the forestry sector in order to overcome the colonial legacy characterised by bureaucratic and revenue oriented management, widespread isolation from community by ignoring their traditional rights, 
indigenous knowledge and resource use practices (Khan 2009). The participatory concepts of forestry dealing and engaging local people as participants officially coined through community forestry projects that further expanded and replicated through various projects such as TANDP, FSP, CGP and Sundarbans Biodiversity Project (Muhammed et al. 2005). Although these projects made significant provision for community involvement in the name of participants, the nature and extent of participation varied significantly that is also influenced by the governance mechanism (Chowdhury 2005). The following discussion attempts to highlight the salient features of the various projects in relation to participation and governance.

\section{Community Forestry Project}

This is a pioneer attempt of the Bangladesh Forest Department (BFD) with an objective of benefiting rural poor by producing fuel wood for domestic uses, fruits, construction timber, and fodder and to mobilise community towards tree plantation. It spanned from 1981-1988. Institutional capacity building of the BFD was also among the other agendas with a view to expanding social forestry throughout the country. The project was implemented in seven North-western districts of Bangladesh with the financial assistance of Asian Development Bank (ADB) as loan grant (Khan et al. 2004). Patches of Sal forest ${ }^{3}$ and marginal lands were brought under the project jurisdiction.

The project sets various physical targets such as establishment of strip plantation, wood lot plantation, agro-forestry, training and institutional support. Although it succeeded to achieve majority of the physical targets but the development in terms of social goals were very limited (Khan et al. 2004). Farmers were indifferent to the seedlings provided by the authority as their choices of species were not reflected during plantation stage. The extension service was even inadequate at farmers' level. The major limitation of the project in terms of community engagement was that, it failed to come up with a written and formal agreement of the specific rights to benefit over the resources upon maturity hence failed to draw mass attention of the local community. Despite creating a good number of short term employment opportunities in nurseries and plantations the governance issue was still fully ignored or absent.

\section{Thana Afforestation and Nursery Development Project}

Thana Afforestation and Nursery Development Program (TANDP) was a follow-up project of the Community Forestry Project also supported by ADB loan. The project spanned over a period of 1989-1996. It also aimed at increasing the production of biomass fuel, enhancing institutional capacity of BFD to enable them in implementing a self-sustaining SF

\footnotetext{
${ }^{3}$ One of the major forest types of Bangladesh characterized by dry and deciduous tree species.
} 
programme. TANDP managed to fulfil its physical target like the previous project. However, this project significantly varies from the previous one in terms of operational area since it covered almost whole Bangladesh (61 out of 64 districts of Bangladesh). Forest lands were mainly brought under the project (Khan et al. 2004). The level and content of community participation varied significantly. The community participation was mainly for the protection of the planted trees in strip or in block plantation. Absence of the scopes of harnessing immediate benefits and the land tenural insecurity adversely influenced the notion of participation. This is also influenced by the patronage relation between poor farmer and local elites (Das 2008). The institutional capacity building of the BFD was also experienced several complexities since a large section of the project staffs were recruited on temporary basis that significantly influenced the overall governance of the project.

\section{Forestry Sector Project}

Forestry Sector Project widely known as FSP was another development support in forestry sector by ADB implemented during the period of 1996-2004. It was the largest public sector intervention on social forestry (SF) in Bangladesh. The designated aims of the project included conservation of forest in selected PAs, increase wood production, institutionalization of forest resource management through community participation, institutional capacity building and policy reform. According to ADB Mission Report, the project was a successful one although some of the components like protection of the natural forest through community participation failed to achieve the target (Khan et al. 2004).

A significant achievement took place during the project tenure in terms of institutional and policy reforms. The Forest Act, 1927 was amended in the year 2000 and broad stakeholder consultation took place to finalise draft rules and regulations to provide a legal shape to SF. However, the Indigenous and ethnic minority groups questioned the process of consultation. The positive side of the project is that, it involved a considerable number of local development organizations as partners in the implementing process. The project succeeded in increasing the green coverage of the country through partnership initiative (public-private-NGOs) but the issues of governance still remain unattended.

\section{Sundarbans Biodiversity Project}

The Sundarbans Biodiversity Project widely known as SBCP was also an initiative through ADB loan support implemented with a view to ensuring sustainable management and conservation of the biodiversity of Sundarbans Reserve Forest. The project aimed at the reduction of poverty of 3.5 million people living in and around the impact zone of Sundarbans by adopting the following participatory approaches for social development in the impact zone:

- Assessment of base line data to determine socio-economic condition;

- Organizing and mobilising the resource users; 
- Creation of alternative source of micro-credit support to the community-based groups to create alternative employment opportunities;

- Social infrastructure development.

Although the project designed to implement various components related to participatory management of the Sundarban Reserve Forest but due to the lack of significant progress in community and stakeholder engagement, the project was suspended. Ineffective governance and poor financial management was the major reason behind this suspension. The donor advised BFD to re-formulate the project proposal through active community participation and consultation with various stakeholders as precondition to revive the project.

\section{Coastal Greenbelt Project}

This ADB supported project was specially designed for the coastal districts of Bangladesh with a view to improving the coastal environment by tree plantation and to fight poverty through creating alternative income generation opportunities. The project managed to raise $8934 \mathrm{~km}$ of strip plantation whereby 143936 participants and more than 100 NGOs were directly involved with the project implementation. As per the review report the physical achievement was satisfactory (Millat-e-Mustafa 2002).

It also generated employment and the frequency of women participation in the project was higher compared to other programmes (Millat-e-Mustafa 2002). However, land use and tenural rights remain big issues that significantly influence the notion of active community participation. Public engagement and the process of NGO engagement were criticised by the participants due to the bureaucratic nature of the BFD.

\section{SOCIO-ECONOMiC AND Governance ATtributes of the PARTICIPATORY Forestry ProgramMe}

Participatory forestry officially coined in the name of CF, SF in Bangladesh. Although they made various provisions of participation in the project proposal but the active engagement of community in the decision-making process was obscure. The following discussion examined and summarised the socio-economic and governance attributes based on several evaluation study.

\section{Socio-Economic Attributes}

Various socio-economic attrbutes have directly or indirectly ifleuned the participatory approach of forestry practices popularly known as social forestry. Some of the major findings can be summarized as follows: 
- Participants selection was a crucial factor which in many instances was influenced by patronage relation. A significant portion of participants was drawn from large land owners, local influential and elected representatives of the local government bodies. Such inclusion of elite members forced to obscure the voice of the grassroots people in management and governance.

- Women participation in planning and decision-making process was marginal. However, their involvement in protection and maintenance of the plantation was significant.

- Participants received a good amount of money as share of the harvested products. They invested the received amount for various purposes such as debt repayment, purchasing of farming animals, buying land and in small business.

- Participants received training on plantation technique and management both by BFD and NGOs. Community organising and mobilising strategy training was provided to BFD officials as well as to the participants that helped increasing awareness regarding participatory forestry approaches.

- Participatory forestry in the name of CF, SF enabled participants to be more respectable within community. Their economic solvency helped to uplift their status and recognition in the society. However, access to better health, education and sanitation still remain as a far reaching goal.

\section{Governance}

Passive community participation was experienced. Participants were not actively involved in the planning, monitoring and group formation process. BFD or nominated NGOs were mainly engaged in accomplishing all these activities. However, in some project areas BFD informed the participants about the project and the potential benefits of involvement as participants in the project.

- The species choice for plantation was even decided and directed by the BFD and accordingly arrangements were made that significantly influenced the participation process as participants were confused about the future existence of the programme (assumed it as an another adhoc intervention.

- BFD was all in all in taking and implementing the decisions. Formal procedures were maintained just by informing and receiving approval from the Upazilla and District ${ }^{4}$ Coordination Committees related to forestry.

- In some project location participants expressed a sense of ownership which is manifested by regular contacts with BFD people, regular vigilance of plantation site and presence in meeting

- The coordination among various stakeholders was not satisfactory. Top-down management approach was still dominating in the process in the name of participatory forestry.

\footnotetext{
${ }^{4}$ Local administrative units under the jurisdiction of the division. There are 64 districts in Bangladesh. Each of them again divided into several sub-districts called Upazilla.
} 


\section{Co-Management as a Tool of Protected Area Governance IN BANGLADESH}

The major weakness of forest management in Bangladesh is the incapability to ensure participation of the forest dependent community (Nath and Inoue 2010). Participation in governance and the necessary legal and policy frameworks was weak as noticed in many forestry projects of Bangladesh. Although most of the participatory forestry projects have managed to achieve physical targets but meeting social targets of community participation and equitable distribution of share and rights were still lacking (Nath and Inoue 2010). The top-down approach was still persisting that ignored the rich history of traditional practice and knowledge base. Recognising the weakness of the conventional forest management and the continued depletion and degradation of the forest resources, the government started establishing PAs since 1980s and gradually adopted legal frameworks for community participation in governance through co-management approach (Rashid et al. 2013b). However, the declaration of these PAs adds little to the conservation and management of depleting biodiversity because of the predominant classical approach to management with an ecological focus that often excludes local rights and practices (Mukul et al. 2010; Mukul and Quazi 2009).

The co-management concept was first adopted for the aquatic resource management in the name of MACH (Management of Aquatic Ecosystems through Community Husbandry) during 1998 on pilot basis with a view to addressing poverty and ensuring sustainable management of wetland and aquatic resources through engaging local community in decisionmaking process (Quazi et al. 2008). Based on the relative success of this project, the government of Bangladesh with the active support of USAID took a similar pilot project for the management of the PAs in the name of Nishorgo Support Project (Biswas and Chowdhury 2011). In Bangladesh the PAs quite often overlap with the forest area since most of the PAs are the forest PAs ${ }^{5}$. These PAs represent three major forest types of Bangladesh namely Hill forest, Sal Forest and Mangrove Forest and belongs to the IUCN Guidelines of PA Management Categories II and IV (Dudley 2008). After the completion of NSP, the forest department undertook new initiative under the financial assistance of USAID to scale up the co-managemnet in other PAs under the project titled Integrated Protected Area Comanagement (IPAC) that continues from 2008-2013. Governance attributes were given priority in the second phase of co- management program. Based on the relative success of the IPAC, another project intervention was devised in the year 2013 titled Climate Resileint Ecosystem and Enhanced Livelihoods (CREL) that has also included wetlands in addition to forest PAs.

\section{The Nishorgo Protected Area co-Management Initiatives}

Nishorgo Support Programe was based on the normative framework of conserving vanishing forest biodiversity and ensuring livelihood support for the local community

\footnotetext{
${ }^{5}$ A subset of all protected areas that includes a substantial amount of forest. This may be the whole or part of a protected area managed for biodiversity conservation and associated cultural values.
} 
dependent on PAs (Khan 2008). NSP selected 5 PAs as pilot sites in order to develop a model that further replicated gradually to the other PAs of the country (Quazi et al. 2008). As a consequence of this development co-managemnet approach has sacled up to 18 Pas till todate. The main focus of the co-management approach under NSP includes protection and conservation of all natural forest and its biodiversity, conversion of monoculture of exotic tree species with indigenous species, development of co-management agreements with key stakeholders and capacity building of the BFD for better administrative, management and policy support for the PAs (Sharma et al. 2008).

Most of the PAs of Bangladesh are part of some reserved forest (RF) and are subject to massive exploitation by neighbouring people for subsistence and income for years. One of the key challenges for Nishorgo in these PAs was therefore, to provide people with alternative income generating (AIG) options to divert their dependency on forests and forest products. However, as the effort was limited by resources, it was obviously impossible to bring the entire forest dependent community under the umbrella of AIG. To promote participation in park management and decision making process Nishorgo formed some legal institutions in the name of Co-management Councils and Co-management Committee (CMC) in each of the pilot sites taking representatives from all stakeholder groups including representatives from government. There were regular monthly meetings in these sites where members of the committee were informed any progress or initiatives taken in their respective PA and had chance to share their views, needs and/or any recommendations for better management of the park.

Based on the relative success of the NSP, the concept was further expanded in other protected areas with the intervention of new projects named Integrated Protected Area Comanagement (IPAC) and Climate Resilient Ecosystem and Livelihood (CREL) addressing various dimensions of collaborative PA governance.

\section{GOVERNANCE AND INSTITUTIONAL ATTRIBUTES: EXPERIENCES FROM THE EMPIRICAL STUDIES}

Empirical studies were conducted in two of the pioneer PAs namely Chunati Wildlife Sanctuary and Lawachara National Park. Focused Group Discussion (FGD), semi-structured interview, key informant interview and personal observation were the major tools used to obtain required information. Monthly meeting of the co-management committee (CMCs) were attended apart from visiting their official documents. Secondary data and informations were also referred to ascertain the governance and institutional aspects of the PAs.

\section{Chunati Wildlife Sanctuary}

Chunati Wildlife Sanctuary (CWS) is particularly important as it is the habitat and an important corridor for Asian elephants. Furthermore, a significant number of local people are directly or indirectly dependent on this sanctuary for their livelihood. CWS is part of the southern cluster of IPAC managed PA where co-management is in practice from NSP period. The field work conducted during the period of July, 2010 - January, 2011 reveals that institutional and legal framework in support of the co-management approach significantly 
influence the governance issue. Currently two CMC are in operation in CWS (one in Chunati range and the other in Jaldi range). Based on the physical visits, follow up of the monthly meeting of CMC, FGD and in-depth interview with the various stakeholders; it revealed that CMCs are embraced with following challenges:

- The CMCs are still dominated by the elite peoples. No significant voice of the community people has so far been noticed, although the number of members in CMC have been increased through legal notification to ensure more representation of the vulnerable groups namely, FUG, CPG, ethnic minority, woman etc.;

- Trust and performance is the key to governance which was missing in the study area. Local forest officials in general do not own the concept of co-management. Monthly meetings are still arranged and initiated by the IPAC staffs whereas being a Member Secretary; it is the responsibility of the respective Range Officer to take all initiatives regarding arrangement of the monthly meeting.

- Encroachment is a critical issue in CWS. One third of the area has already been encroached and turned to o agricultural land. Such uncertainities influenced forest dependent people to resratin from participarting in the co-management initiatives. Local forest department also has failed to create their image that can satisfy community with assurance;

- Political manipulation $\mathrm{t}$ is a growing concern in any NRM project like comanagement in PAs. Development partners hardly allocate any budget for that, which is adversely affecting the overall governance;

- Legal atrubutes like acts, rules, policies etc. are not clearly and widely shared to the community. Such limitation is creating confusion and conflicting situation between BFD and community. With the promulgation of SF Rules of 2010 (amended), a vast forest area further goes under the control of local political elites in the name of public-private partnership as optioned in the amendment;

- Ambiguity of both BFD and CMC regarding transparency and accountability is further deteriorating the situation;

- Sustainability of CMC is a critical issue since there is no provision of resource support either internally or externally. Due to the absence of self funding sources the CMCs can not undertake any development projects on their own; 
Table 1. Legal, policy and institutional attributes affecting PA governance in Bangladesh

\begin{tabular}{|c|c|c|c|c|c|}
\hline \multirow{2}{*}{$\begin{array}{l}\text { Issues affecting PA governance } \\
\text { (when CMC is an institution) }\end{array}$} & \multicolumn{5}{|c|}{ Key findings } \\
\hline & Legal and policy issues & $\begin{array}{l}\text { BFDs role in implementing } \\
\text { co-management }\end{array}$ & Community participation & $\begin{array}{l}\text { Co-management as an } \\
\text { governance option }\end{array}$ & NGOs role \\
\hline \multirow[t]{2}{*}{ Dominated by elite members } & $\begin{array}{l}\text { Supportive but problem with } \\
\text { implementation }\end{array}$ & $\begin{array}{l}\text { Still dominated by command } \\
\text { and control management }\end{array}$ & $\begin{array}{l}\text { Passive engagement like } \\
\text { SF,CF }\end{array}$ & $\begin{array}{l}\text { Good platform to enhance } \\
\text { accountability, responsibility, } \\
\text { legitimacy and voice of multi- } \\
\text { stakeholders }\end{array}$ & $\begin{array}{l}\text { Better } \\
\text { acceptance by } \\
\text { the development } \\
\text { partners }\end{array}$ \\
\hline & $\begin{array}{l}\text { Needs to formulate rules and } \\
\text { procedures related to joint or } \\
\text { collaborative management }\end{array}$ & Not conducive for SD & $\begin{array}{l}\text { Decision-making process } \\
\text { still dominated by BFD } \\
\text { and elite members. } \\
\text { Members representing } \\
\text { vulnerable and grass root } \\
\text { community remain } \\
\text { inactive. }\end{array}$ & $\begin{array}{l}\text { Concept needs to be location } \\
\text { and individual need based } \\
\text { under the notion of Common } \\
\text { but differentiated responsibility }\end{array}$ & $\begin{array}{l}\text { Strong footing } \\
\text { for community } \\
\text { mobilization }\end{array}$ \\
\hline $\begin{array}{l}\text { Enhanced connection between } \\
\text { BFD and community }\end{array}$ & $\begin{array}{l}\text { Adhoc nature of the projects } \\
\text { affecting the proper } \\
\text { implementation }\end{array}$ & $\begin{array}{l}\text { Co-management is yet to be } \\
\text { accepted at every level }\end{array}$ & \begin{tabular}{|l|} 
Benefit driven \\
participation
\end{tabular} & $\begin{array}{l}\text { Lacking with orientation at } \\
\text { community level. People still } \\
\text { perceive PAs as a recreational } \\
\text { place }\end{array}$ & \begin{tabular}{|l} 
Absence of \\
skilled \\
manpower \\
particularly \\
technical staffs \\
\end{tabular} \\
\hline $\begin{array}{l}\text { Absence of long term vision and } \\
\text { strategic planning }\end{array}$ & $\begin{array}{l}\text { Forest offenses are not } \\
\text { addressed immediately }\end{array}$ & $\begin{array}{l}\text { Concentrating more on } \\
\text { achieving physical targets } \\
\text { (i.e., increase in plantation } \\
\text { coverage) }\end{array}$ & $\begin{array}{l}\text { Excessive operational } \\
\text { expenses affecting AIG } \\
\text { activities }\end{array}$ & $\begin{array}{l}\text { Creates scopes for shifting the } \\
\text { governance paradigm }\end{array}$ & $\begin{array}{l}\text { The contracting } \\
\text { nature and scope } \\
\text { of work needs } \\
\text { re-consideration } \\
\text { for better } \\
\text { performance } \\
\end{array}$ \\
\hline $\begin{array}{l}\text { Poorly funded hence affecting } \\
\text { sustainability and better } \\
\text { community engagement }\end{array}$ & $\begin{array}{l}\text { Political influence is a big } \\
\text { challenge at field level }\end{array}$ & $\begin{array}{l}\text { Failed to materialize the } \\
\text { integration of livelihood for } \\
\text { PA management }\end{array}$ & & $\begin{array}{l}\text { Needs resource and technical } \\
\text { support to mainstream the } \\
\text { concept }\end{array}$ & \\
\hline $\begin{array}{l}\text { Completely dependent on project } \\
\text { support(i.e., physical, technical, } \\
\text { financial assistance) }\end{array}$ & & & & & \\
\hline
\end{tabular}


- As a shared governance approach, both BFD and the committee members needs to participate actively to develop plans and programs for the sustainable management of the respective PAs and livelihood aspect of the forest dependent community. However, BFD representative was found reluctant in arranging monthly meetings and determining agends pertinent for the PA and its development.

- Political governance is also significantly affecting the notion and zeal of the participation. In one of the study area CMC meeting was suspended consecutively for 3 months as the chairman was unable to present. He was even reluctant in giving consent to arrange the meeting headed by the vice-chairman of the $\mathrm{CMC}$;

- Accountability, transparency, legitimacy and voice are the preconditions for ensuring good governance. Adhoc nature of the projects in NRM sector is one of the impediments to achieve desired goals.

Various stakeholders were interviewed to ascertain the multiple aspects related to PA management. Table 1 present glimpse of the salient features raised by the respondents from different quarters having stakes in the implementation of the co-management approach in the PAs of Bangladesh.

\section{Lawachara National Park}

Lawachara is famous for its' rich faunal diversity, particularly for one of the largest population of critically endangered Hollock gibbons in south-east Asia. The park is also inhabited by several indigenous communities including Khasia and Tripura, who have been enjoying the usufruct right to use a limited forest area within the park for their traditional betel vine (Piper betel) and lemon (Citrus limon) cultivation. One of the Nishorgo initiatives in the park was, recruiting former illegal loggers as Community Petrol Group (CPG) members to protect poaching of valuable timber from the park area. All the participants were paid lump sum remuneration and basic gears for their protection service, and the effort brought a noticeable change in the area whereby significant reduction was experienced in illegal forest activities (Mukul et al. 2014). Furthermore, such effort also adds a vibrant impact on enriching floral and faunal biodiversity. However, the enthusiasm and the efforts have started fading with time due to several reasons i.e., absence of monitoring by CMC, lack of support from the project and reluctance of the field staffs belonging to the BFD. Such limitations in co-management concept are adversely affecting the governance mechanism. Figure 1 below shows the illegal logging (in terms of no. of trees felled illegally) in Lawachara National Park (blue line) with other Nishorgo pilot sites between four different periods. It is clear from the graph that, the number of trees illegally felled during 2003-04 period was about 1,200 , being the highest amongst the pilot sites, which fell down to about 400 during 2006-07 period (Mazumder et al. 2007).

Another interesting observation from this pilot site was that, involving local people in forest PA conservation with clearly defined tenural rights could significantly boost-up conservation effort provided their life and living are in harmony with the forest (Mukul et al. 2014). 


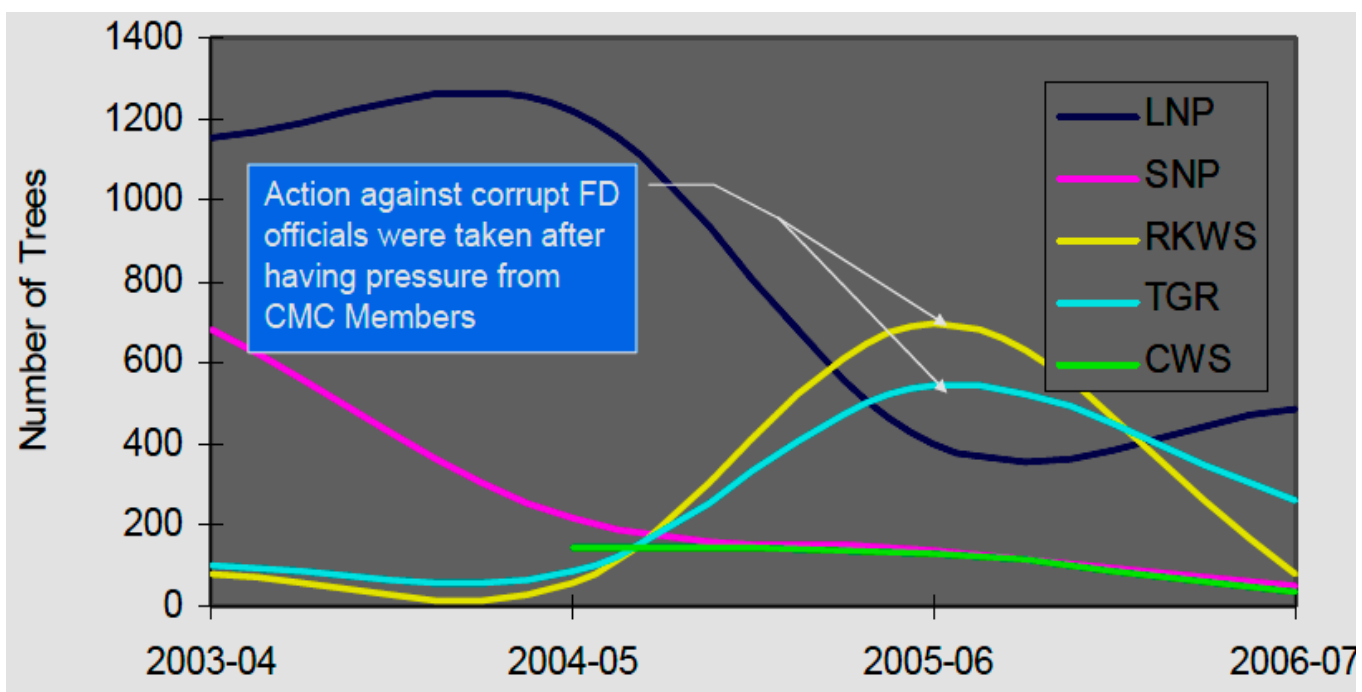

Figure 1. Illegal tree felling at different Nishrogo pilot sites.

(Source: Mazumder et al. 2007)

\section{Clues for Future DevelopMent}

Based on the outcomes of the empirical studies as well as from opinion of the various stakeholders, it is quite evident that, co-management activities in PA sites has brought slow but explicit changes whereby decentralized, site specific and community based activities are gradually taking the place of centralized classical approach to some extent. Households who were previously plunderers are now active forest protectors. Now communities are more aware regarding conservation attributes which needs further and long term nourishment to bring positive changes. To ensure long term sustainability in conservation and better forest governance, it is very essential to focus on generous socio-economic upliftment of the communities living on forests, and ensure equity in benefit sharing. Attitudinal changes of the forest department and its officials towards the shifting paradigm of PA management are crucial in this regard. To avoid conflict, and promote traditional livelihoods of the communities, there is also the need to allow people harvesting certain amount of forest products ensuring ecological sustainability (Mukul et al. 2016, 2010). Financial and technical sustainability of the CMC's must be ensured through innovative mechanism (i.e., continuous training for capacity building, provision of direct grants to CMC; linking with external and internal funding agencies, funding through international negotiable instruments viz. REDD+) followed by constant supervision and monitoring. Finally, legal and policy support to adore the concept is important since it is the precondition to bring better governance in management. Above all, the foremost important thing is to keep the process free from politicization.

Adhoc nature of the projects is one of the limiting factors as we have seen in various participatory forestry projects. Such short term nature programmes are also weakening the institutional and individual capacity building process. In order to overcome these barriers we need to mainstream the project through sourcing internal fund i.e., revenue budget. 
Continuation of the programme will not only increase the accountability and transparency but will also help to build confidence among the participants to be involved in the process. Institutional capacity building both for the BFD and $\mathrm{CMC}$ is crucial. Training, logistic support, financial incentives and strict monitoring and evaluation process can ensure better governance to harvest better management outcome.

Development organizations are playing significant role for community mobilization and efficient utilization of the resources needed for the project management. Furthermore, credibility of the NGOs is more to development partners for their better monetary management. However, they cannot be the replacement of the state institutions such as BFD who has the mandate, legitimacy and nationwide technical strength and physical coverage to disseminate various concepts and attributes of NRM especially in the PA sector. Thus developing a credible public-private partnership can be a desired option. Good governance in PA management through active community and stakeholder participation may add significantly to the journey of sustainable natural resource governance.

\section{REFERENCES}

Abrams, P., Borrini-Feyerabend, G., Gardner, J., Heylings, P. 2003. Evaluating Governance$A$ handbook to accompany a participatory process for a protected area. Parks Canada and TILCEPA, IUCN.

Alam, M. 2009. Evolution of forest policies in Bangladesh: a aritical analysis. International Journal of Social Forestry 2: 149-166.

Ali, M., Kabir, M.A., Hoque, A.T.M.R. 2006. People's attitude and use of forestland: coevolution of forest administration in Bangladesh. Small-scale Forest Economics, Management and Policy, 5: 271-286.

Appanah, S., Ratnam, L. 1992. The importance of forest biodiversity to developing countries in Asia. Journal of Tropical Forest Science, 5: 201-215.

Balloffet, N.M., Martin, A.S. 2007. Governance trends in protected areas-experiences from the parks in peril program in Latin America and the Caribbean. The Nature Conservancy, USA.

Bangladesh Forest Department (BFD). 2016. Biodiversity and wildlife conservation (in Bengali). URL: http://www.bforest.gov.bd.

Berkes, F. 2003. Evolution of co-management: role of knowledge generation, bridging organizations and social learning. Journal of Environmental Management, 90: 16921702.

Biswas, G., Chowdhury, A.M. 2011. Protected area co-management lessons learned: comanagement organization (CMO) perspective. Paper presented in the $1^{\text {st }}$ Bangladesh Forestry Congress, Bangladesh Forest Department, Dhaka.

Biswas, S.R., Choudhury, J.K. 2007. Forest and forest management practices in Bangladesh: the question of sustainability. International Forestry Review, 9: 627-640. 
Borrini-Feyerabend, G, Kothari, A., Oviedo, G. 2004: Indigenous and local communities and protected areas-towards equity and enhanced conservation. Best Practice Protected Area Guideline Series No. 11. Cardiff University, UK and IUCN, WCPA, Switzerland.

Borrini-Feyerabend, G. 2003. Governance of protected areas- innovation in the air. Policy Matters 12: 92-101.

Borrini-Feyerabend, G., Johnston, J., Pansky, D. 2006. Governance of protected areas. In: Lockwood, M., Worboys, G., Kothari, A. (eds). Managing Protected Areas: A Global Guide. Earthscan Publications, London, UK.

Borrini-Feyerbend, G. 2002. Indigenous and local communities and protected areas: rethinking the relationship. Parks, 12: 5-15.

Bosselmann, K., Engel, R., Taylor, P. 2008. Governance for sustainability: issues, challenges, success. IUCN Environmental Policy and Law Paper No. 70, IUCN, Switzerland.

Carter, J.S., Kaspar, R., Patrick, S.T., Nizami, A. (eds). 2009. Forests, landscapes and governance- multiple actors, multiples roles. Swiss Agency for International Cooperation.

Chape, S., Blyth, S., Fish, L., Fox, P., Spalding, M. (eds). 2003. United Nations list of protected areas. The World Conservation Union (IUCN), Gland, Switzerland, and UNEPWCMC, Cambridge, UK.

Chowdhury, M. S. H., Koike, M., Muhammed, N. 2009. Embracing collaborative protected area management for conservation: an analysis of the development of the forest policy of Bangladesh. International Forestry Review, 11: 359-374.

Chowdhury, S.A. 2005. Participation in forestry: the role of bureaucrats in ensuring peoples participation in the social forestry policy of Bangladesh. Asian Affairs, 27: 75-99.

Craig, D. 2002. Recognizing indigenous rights through co-management regimes: Canadian and Australian experiences. New Zealand Journal of Environmental Law, 6: 199-254.

Craig, D. 2006. Negotiating indigenous co-management: Canadian comprehensive land claims agreements and other experiences. Paper presented at the conference on Relationship between Aboriginal People and Land Management Issues in NSW-Barriers and Bridges to Successful Partnership. University of Wollongong, Australia.

Cronkleton, P., Barry, D., Pulhin, J., Saigal, S. 2010. The devolution of management rights and the co-management of community forests. In: A.M. Larson, D. Barry, G.R. Dahal and C.J.P. Colfer (eds). Forest for People-Community Rights and Forest Tenure Reform. Earthscan, London, UK.

Dahal, G.R. 2003. Devolution in the context of poor governance: some learning from community forestry in Nepal. Journal of Forest and Livelihood, 2: 17-18.

Das, M.K. 2008. Proshika: Marginalized peoples participation in rural afforestation in Bangladesh. International Journal of Social Forestry, 1: 184-193.

Dearden, P., Bennett, M., Johnston, J. 2005. Trends in global protected area governance, 1992-2002. Environmental Management, 36: 89-100.

DeFries, R., Hansen, A., Turner, B.L., Reid, R., Liu, J. 2007. Land use change around protected areas: management to balance human needs and ecological function. Ecological Application, 17: 1031-1038.

Dubois, O., Lowore, J. 2000. The journey towards collaborative forest management in Africa: lessons learned and some navigational aids. An overview. Forestry and Land Use Series No.15, IIED, London.

Dudley, N. 2008. Guidelines for applying protected area management categories. WCPA, IUCN, Gland, Switzerland and Cambridge, UK. 
Fabricius, C., Koch, E., Magome, H. 2001. Towards strengthening collaborative ecosystem management: lessons from environmental conflict and political change in Southern Africa. Journal of the Royal Society of New Zealand, 31: 831-832.

FAO. 2009. State of the World's Forests 2009. Food and Agriculture Organization of the United Nations (FAO), Rome, Italy.

Ferrari, F.M. 2006. Rediscovering community conserved areas in South-east Asia: peoples initiative to reverse biodiversity loss. Parks 16: 43-48.

Fisher, R.J. 2003. Innovations, persistence and change: reflections on the state of community forestry. In: The Community forestry current innovations and experiences, pp. 16-29. Regional Community Forestry Training Center (RECOFTC) and FAO-Regional Office for Asia and the Pacific (FAO-RAP), Bangkok, Thailand.

Ghimire, K.B. 1994. Parks and people: livelihood issues in national parks management in Thailand and Madagascar. Development Change, 25: 195-229.

Jeanrenaud, S. 2002. People-oriented approaches in global conservation: Is the leopard changing its spots? International Institute for Environment and Development (IIED), London, UK and Institute for Development Studies (IDS), Brighton, UK.

Jeffery, M.I. 2004. An international legal regime for protected areas. In: J. Scanlon and F. Burhenne-Guilmin (eds). International Environmental Governance- An International Regime for Protected Areas. IUCN Environmental Policy and Law Paper No. 49: 9-40.

Kaimowitz, D., Sheil, D. 2007: Conserving what and for whom? Why conservation should help meet basic human needs in the tropics. Biotropica, 39: 567-574.

Khan, N.A. 1998. Land tenural dynamics and participatory forestry management in Bangladesh. Public Administration and Development, 18: 335-347.

Khan, N.A. 2009. More than meets the eye: Re-reading forest policy discourse in Bangladesh. QEH Working Paper Series No.177, University of Oxford, UK.

Khan, N.A., Choudhury, J.K., Huda, K.S., Mondol, M.I. 2004. An overview of social forestry in Bangladesh. Government of Bangladesh and University of Chittagong.

Kothari, A., Pathak, N., Vania, F. (eds). 2000. Where communities care: community-based wildlife and ecosystem management in South Asia. Kalpavriksh, Pune, India and IIED, London, UK.

Koziell, I., Saunders, J. (eds). 2001. Living off biodiversity: exploring livelihoods and biodiversity. IIED, London, UK.

Lockwood, M. 2010. Good governance for terrestrial protected areas: a framework, principles and performance outcomes. Journal of Environmental Management, 91: 754-766.

Mazumder, A.H., DeCosse, P., Sharma, R., Ahmad, I.U. 2007. Forest conservation in Bangladesh: tracing its ebb and flow in recent decades, with observation for the future. Paper presented in international conference 'The Future of Forests in Asia and the Pacific: Outlook for 2020' held in October 16-18, 2007 at Chiang Mai, Thailand.

McNeely, J., Faith, D.P., Albers, H.J. 2006. Biodiversity: In: Ecosystems and Human WellBeing: Policy Response. Island Press, Washington DC.

McNeely, J., Scherr, S. 2003. Eco-agriculture: strategies to feed the world and conserve wild biodiversity. Island Press, Washington DC, USA.

Mehta, J.N., Heinen, J.T. 2001. Does community-based conservation shape favourable attitudes among locals? an empirical study from Nepal. Environmental Management 28: 165-174. 
Millat-e-Mustafa, M. 2002. A review of forest policy trends in Bangladesh - Bangladesh Forest Policy Trends. Policy Trend Report, 2002: 114-121.

Muhammed, N., Koike, M., Haque, F. 2008. Forest policy and sustainable forest management in Bangladesh: an analysis from national and international perspectives. New Forests, 36: 201-216.

Muhammed, N., Koike, M., Sajjaduzzaman, M., Sophanarith, K. 2005. Reckoning social forestry in Bangladesh: Policy and plan versus implementation. Forestry 78: 373-383.

Mukul, S.A., Herbohn, J., Rashid, A.Z.M.M., Uddin, M.B. 2014. Comparing the effectiveness of forest law enforcement and economic incentive to prevent illegal logging in Bangladesh. International Forestry Review, 16: 363-375.

Mukul, S.A., Rashid, A.Z.M.M., Quazi, S.A., Uddin, M.B., Fox, J. 2012. Local peoples' response to co-management in protected areas: A case study from Satchari National Park, Bangladesh. Forests, Trees and Livelihoods, 21: 16-29.

Mukul, S.A., Rashid, A.Z.M.M., Uddin, M.B., Khan, N.A. 2016. Role of non-timber forest products in sustaining forest-based livelihoods and rural households' resilience capacity in and around protected area: a Bangladesh study. Journal of Environmental Planning and Management, 59: 628-642.

Mukul, S.A., Uddin M.B., Uddin M.S., Khan M.A.S.A., Marzan B. 2008: Protected areas of Bangladesh: current status and efficacy for biodiversity conservation. Proc. Pakistan Acad. Sci., 45: 59-68.

Mukul, S.A., Uddin, M.B., Rashid, A.Z.M.M., Fox, J. 2010. Integrating livelihoods and conservation in protected areas: understanding the role and stakeholder views on prospects for non-timber forest products, A Bangladesh case study. International Journal of Sustainable Development and World Ecology, 17:180-188.

Mukul, S.A., Quazi, S.A. 2009. Communities in Conservation: Changing protected area management and enhanced conservation in Bangladesh. In: Leslie, R.N. (ed). 'The Future of Forests in Asia and the Pacific: Outlook for 2020'. Food and Agriculture Organization of the United Nations, Bangkok, Thailand (FAO-RAP Publication no 2008/3). 143-159 pp.

Nagothu, U.S. 2003. Local people's attitudes towards conservation and wildlife tourism around Sariska Tiger Reserve, India. Journal of Environmental Management, 69: 339347.

Nath, T.K., Inoue, M. 2010. Impacts of participatory forestry on livelihoods of ethnic people: experience from Bangladesh. Society and Natural Resources, 11: 1093-1107.

Naughton-Treves, L., Holland, M.B., Brandon, K. 2005. The role of protected areas in conserving biodiversity and sustaining local livelihoods. Annual Review of Environment and Resources, 30: 219-252.

Nepal, S.K., Weber, K.E. 1995. Managing resources and resolving conflicts: national parks and local people. International Journal of Sustainable Development and World Ecology, 2: $11-25$.

Orlovic-Lovren, V. 2011. The role of education in protected area sustainable governance. Management of Environmental Quality, 22: 48-58.

Ormsby, A., Kaplin, B.A. 2005. A framework for understanding community resident perceptions on Masoala National Park, Madagascar. Environmental Conservation, 32: $156-164$. 
Poffenberger, M. (ed). 2000. Communities and forest management in South Asia. IUCN, DFID and Asia Forest Network, Indonesia.

Quazi. S.A., Bushley, B.R., Miles, W.B. 2008. Introduction: Participation and the Collaborative Management of Protected Areas in Bangladesh In: Jefferson Fox et al. (eds). Connecting Communities and Conservation: Collaborative Management of Protected Areas in Bangladesh East West Center, USAID.

Rashid, A.Z.M. M., Khan, N.A., Alam, M. 2007. The road down to Rio: Policy responses and implementation of international conventions in Bangladesh. Journal of Business and Society, 4: 10-15.

Rashid, A.Z.M.M., Craig, D., Mukul, S.A., Khan, N.A. 2013a. A journey towards shared governance: status and prospects of collaborative management in the protected areas of Bangladesh. Journal of Forestry Research, 24: 599 -605.

Rashid, A.Z.M.M., Craig, D., Jeffery, M.I., Khan, N.A., 2013b. Forest protected area governance in Bangladesh: A focus on the legal and policy framework. Chinese Journal of Population, Resources and Environment, 11: 345-351.

Rogers, P.P., Jalal, K.F., Boyd, J.A. 2008. An introduction to sustainable development. Earthscan, London, UK.

Roy, M.K., DeCosse, P. 2006. Managing demand for protected areas in Bangladesh: poverty alleviation, illegal commercial use and nature recreation. Policy Matters, 14.

SCBD (Secretaiat of the Convention on Biological Diversity). 2008. Governance as key for effective and equitable protected area systems. Briefing Note No. 8 (Programme of Works on Protected Areas), SCBD, Montreal, Canada.

Scherr, S.J., White, A., Kaimowitz, D. 2004. A new agenda for forest conservation and poverty reduction _ making markets work for low-income producers. Forest Trends, Washington DC, USA, CIFOR, Bogor, Indonesia, and IUCN, Cambridge, UK.

Sharma, R., DeCoss, P., Roy M., Khan, M., Mazumder, A. 2008. Co-management of protected areas in South Asia with special reference to Bangladesh. Nishorgo Support Project of Bangladesh Forest Department, Dhaka.

Wells, M.P., Mcshane, T.O. 2004. Integrating protected area management with local needs and aspirations. Ambio, 33: 513-519.

World Resources Institute. 2007. Earth trends: the environmental information portal. URL: http://earthtrends.wri.org.

(C) 2016 by the authors; licensee Preprints, Basel, Switzerland. This article is an open access article distributed under the terms and conditions of the Creative Commons by Attribution (CC-BY) license (http://creativecommons.org/licenses/by/4.0/). 